\title{
Erratum to: The Function of the Medieval in Jean-Jacques Rousseau's Nouvelle Hélö̈se: A Rereading of the Abélard and Héloïse Motif
}

\author{
Alicia C. Montoya
}

Published online: 12 June 2011

(C) Springer Science+Business Media B.V. 2011

\section{Erratum to: Neophilologus (2010) 94:569-584 \\ DOI 10.1007/s11061-010-9204-6}

Unfortunately in the original publication on p. 577, under the second paragraph, the sentence "The Pays de Vaud, in Switzerland, was associated in his mind with his own childhood and with his long-dead "pauvre Maman" (the real one, not Mme de Warens), whose birthplace Vevey was the "petite Ville au pied des Alpes" where the first part of the novel took place" is published incorrectly and should be replaced by the following line "The Pays de Vaud, in Switzerland, was associated in his mind with his own childhood and with his "pauvre Maman" (Mme de Warens), whose birthplace Vevey was the "petite Ville au pied des Alpes" where the first part of the novel took place."

The online version of the original article can be found under doi:10.1007/s11061-010-9204-6.

A. C. Montoya ( $\square)$

Department of Romance Languages and Cultures, Faculty of Arts,

University of Groningen, P.O. Box 716, 9700 AS Groningen, The Netherlands

e-mail: A.C.Montoya@rug.nl 